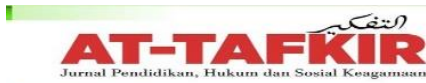 \\ VOLUME 14 NOMOR 1 TAHUN 2021 \\ 10.32505/at.vl4i2.3493
}

\section{Kompetensi Bahasa Inggris Mahasiswa Pendidikan Agama Islam}

\author{
Razali Mahmud*1; Legiman², \\ 1,2Dosen FTIK IAIN Langsa \\ razalimahmud@iainlangsa.ac.id; legiman@iainlangsa.ac.id
}

\begin{abstract}
The purpose of this study is to find out the strategies, barriers, and solutions for improving English language competence for PAI students from the Tarbiyah and Teacher Training Faculty of IAIN Langsa. The research method used is descriptive qualitative method. The research subjects were 12 PAI Study Program students and 3 lecturers who taught English courses at PAI Study Program. The instruments used are interviews and documentation. Data analysis was carried out by data triangulation. The results of the research are (I) Strategies to increase English competence in PAI students by applying various learning strategies to mastering the four English competencies, namely reading, speaking, writing, listening continuously, (2) As for the obstacles in improving English competence in PAI students of the FTIK IAIN Langsa faculty, namely the low English competence of students so that in the process of learning English, they are not so serious and focus on learning. and Learning facilities such as audio-visual are still very limited. The time and number of credits provided is still inadequate in the expected learning process. (3) The solution is that PAI students need to change their main set or their views in studying English courses. They must foster a sense of love and confidence in following the English learning process, from the lecturers, it is hoped that in the learning process they can apply various methods or strategies in order to apply the new strategies found. The faculty is expected to increase the quantity of learning facilities such as audio-visual and others so that the learning process is not constrained or hampered.
\end{abstract}

Keywords; Competence, English, Strategy

\begin{abstract}
Abstrak, Tujuan penelitian ini yaitu untuk mengetahui strategi, hambatan, serta solusi peningkatan kompetensi berbahasa Inggris, pada mahasiswa PAI Fakultas Tarbiyah dan Ilmu Keguruan IAIN Langsa. Adapun metode penelitian yang digunakan yaitu metode kualitatif deskripsi. Subjek penelitiannya 12 mahasiswa Prodi PAI dan 3 dosen yang mengajar mata kuliah Bahasa Inggris di Prodi PAI. Instrumen yang digunakan yaitu wawancara dan dokumentasi. Analisis data dilakukan secara triangulasi data. Adapun hasil penelitian yaitu (1) Strategi peningkatan kompetensi berbahasa Inggris pada mahasiswa PAI dengan menerapkan berbagai strategi pembelajaran terhadap pengusaaan keempat kompetensi Bahasa Inggris yaitu reading, speaking, writing, listening secara kontinu,(2) Adapun hambatan-hambatan dalam meningkatan kompetensi berbahasa Inggris pada mahasiswa PAI fakultas FTIK IAIN Langsa yaitu rendahnya kompetensi berbahasa Inggris mahasiswa sehingga dalam proses pembelajaran bahasa Inggris, mereka tidak begitu serius dan fokus dalam pembelajarannya. serta Sarana pembelajaran seperti audio visual masih sangat terbatas, Waktu dan jumlah sks yang disediakan masih tidak memadai dalam proses pembelajaran yang diharapkan. (3) Solusinya yaitu Mahasiswa PAI perlu merubah maind set nya atau pandangannya dalam mempelajari mata kuliah bahasa Inggris. Mereka harus menumbuhkan rasa cinta dan percaya diri dalam mengikuti proses pembelajaran bahasa Inggris, dari dosen diharapkan dalam proses pembelajaran dapat menerapkan metode atau strategi yang bervariasi agar dapat menerapkan strategi baru yang ditemukan,. Dari Pihak fakultas diharapkan dapat meningkatkan kuantitas sarana pembelajaran seperti audio visual dan lain-lain sehingga proses pembelajaran tidak terkendala atau terhambat.
\end{abstract}

Kata kunci: Bahasa Inggris, Kompetensi, Strategi 


\section{PENDAHULUAN}

Bahasa berperan sebagai alat berkomunikasi dengan orang lain, sehingga kepandaian berbahasa merupakan sesuatu yang penting, terlebih lagi dalam era globalisasi saat ini. Bahasa yang memiliki peran sangat penting yaitu Bahasa Inggris, dimana dikatakan bahwasanya Bahasa Inggris merupakan bahasanya internasional. Oleh karena itu penting mempelajari Bahasa Inggris dikarenakan Bahasa Inggris digunakan dalam berbagai aspek dalam kehidupan seperti dalam dunia pendidikan, pekerjaan, dunia usaha dan juga dunia parawisata, semua menggunakan Bahasa Inggris sebagai Bahasa pengantar. Melihat banyaknya kegunaan dalam berbahasa Iggris, sehingga Bahasa Inggris merupakan pelajaran yang diwajibkan di sekolah-sekolah (Arikunto, 2012).

Persaingan di berbagai dunia kerja menjadikan pembelajaran Bahasa Inggris wajib diterapkan sedini mungkin, setiap sekolah sampai di perguruan tinggi diharuskan meningkatkan kompetensi berbahasa Inggris (Majid, 2018). Hal ini dilakukan agar lulusannya nanti dapat bekerja dalam berbagai bidang usaha, karena di dunia modern ini semua pekerjaan menggunakan mesin dimana petunjuk-petunjuknya menggunakan Bahasa Inggris, dalam bidang komunikasi maka lulusan dapat berkomunikasi Bahasa Inggris dengan baik, sehingga para lulusan dapat bekerja dalam berbagai bidang nantinya(Malan Abdullah, 2012).

Perguruan Tinggi merupakan suatu lembaha pendidikan yang memiliki kontribusi yang besar dalam mengembangkan Sumber Daya Manusia, sehingga di Indonesia dibutukan Sumber Daya Manusia yang sanggup bersaing dengan dunia luar, salah satu yang dapat dilakuakn agar Indonesia sanggup bersaing dengan dunia luar yaitu dengan meningkatkan kompetensi berbahasa Inggris Mahasiswa. Dengan menguasain Bahasa Inggris mahasiswa dapat mengkomunikasikan gagasannya dengan baik di dunia internasional sehingga dpat bersaing dengan berbagai belahan dunia (Sudjana, 2013).

Kurangnya kemampuan berbahasa Inggris mahasiswa merupakan suatu masalah yang sering dihadapi di perguruan tinggi.salah satunya dikarenakan kurangnya keyakinan mahasiswa akan kemampuan dirinya sendiri. Sesungguhnya setiap individu memiliki kompetensi bawaan yang baik. Namun diperlukan suatu keyakinan agar dapat merangsang kompetensi tersebut agar menjadi lebih baik lagi. Kompetensi yang dimaksud disini yaitu suatu keyakinan yang dimiliki seseorang untuk meningkatkan kemampuan akademik dalam bidang Bahasa Inggris (Daryanto, 2009).

Namun Kenyataannya mahasiswa di FTIK prodi PAI pada mata kuliah Bahasa Inggris kurang bisa aktif dalam berbahasa Inggris, hal ini karena mata Kuliah Bahasa Inggris banyak menerapkan latihan-latihan secara tertulis serta menghapal kosakata sehingga mahasiswa tidak dirangsang untuk berkomunikasi dengan baik. Hal ini mengakibatkan mahasiswa ketakutan jika ada matakuliah Bahasa Inggris, karena mereka takut akan hapalan. Namun disisi mahasiswa 
berdasarkan hasil wawancara menyatakan bahwa mereka kurang percaya diri jika dimintakan dosen berkomunikasi dalam Bahasa Inggris, karena kurangnya keyakitan dan motivasi diri mereka untuk belajar Bahasa Inggris. Melihat hal tersebut, seorang dosen harus memilih berbagai metode dalam mengajar, untuk merangsang mahasiswa agar aktif dalam pemebelajaran Bahasa Inggris.

Pada pembelajaran Bahasa Inggris, faktor psikis seperti rasa malu, kurangnya keyakinan, takut salah, kurang percaya diri serat kecemasan yang tinggi dapat memrikan efek kepada kemampuan berbahasa Inggris seorang mahasiswa (Schutz, 2017). Affective Filter Hypothesis mengungkapkan bahwasanya rasa percaya diri, motivasi yang tinggi serta kecemasan berpengaruh terhadap kemampuan berbasa Inggris seseorang. Merujuk pada teori di atas, maka kecemasan merupakan sebagai factor yang perlu mendapat perhatian yang lebih dalm pembelajaran Bahasa Inggris.

Penelitian yang dilakukan oleh Paisal Manurung dan Harry Sambayu (Sambayu, 2015) menitikberatkan tentang kemampuan berbahasa Inggris mahasiswa dengan menggunakan pendekatan kesustrasaan atau Literature Approach pada program studi bahasa Inggris. Metodelogi yang digunakan adalah Class Room Action Research. Namun dilihat dari fokus penelitian, penelitian di atas berbeda dengan rencana penelitian yang akan penulis lakukan yaitu menekankan pada strategi peningkatan berbahasa Inggris pada mahasiswa PAI, (Schutz, 2017)yang merupakan mahasiswa program studi non bahasa Inggris. Fokus penelitian tentang kemampuan empat skill berbahasa Inggris (Reading, Speaking, Listening, dan Writing) juga disertai dengan kemampuan menguasai Vocabularinya.

Berdasarkan latar belakang di atas, yang menjadi tujuan penelitian ini yaitu untuk mengetahui strategi, hambatan, serta solusi peningkatan kompetensi berbahasa Inggris, pada mahasiswa PAI fakultas Tarbiyah dan Ilmu Keguruan IAIN Langsa

\section{METODE PENELITIAN}

Penelitian ini merupakan penelitian kualitatif berjenis penelitian lapangan (Field Research). Penelitian kualitatif merupakan penelitian yang mendeskripsikan hasil dengan kata-kata yang bersifat objektif (Sugiyono, 2017). Adapun lokasi penelitian dilakukan di IAIN Langsa, pada mahasiswa Prodi Pendidikan Agama Islam (PAI) Fakultas Tarbiyah dan Ilmu Keguruan IAIN Langsa yang belajar mata kuliah bahasa Inggris. Dalam penelitian ini peneliti menetapkan responden penelitian menjadi sumber data primer yaitu a) dosen yang mengampu mata kuliah bahasa Inggris pada program studi Pendidikan Agama Islam di Fakultas Tarbiyah, b) mahasiswa program studi Pendidikan Agama Islam karena merekalah yang menjadi subjek dalam penelitian ini. Dalam penetapan responden peneliti menggunakan atau meneliti subjek yang ada di lapangan penelitian dengan 
menggunakan metode purposive sampling. Berkaitan dengan penelitian ini sebagai subjek penelitian difokuskan pada dosen pemangku bahasa Ingrris dan pada mahasiswa prodi PAI sebanyak 3 dosen serta mahaasiswa prodi PAI sebanyak 10 mahasiswa.

Data skunder merupakan sumber data yang diperoleh peneliti secara tidak langsung melalui media perantara. Dalam hal ini sumber data maupun dokumen dari program studi Pendidikan Agama Islam yang berjalan selama ini. Teknik pengumpulan data pada penelitian ini adalah:

a. Wawancara (interview) adalah dilakukan oleh dua belah pihak berupa percakapan yang mendalam dilakuakan secara intensif.

b. Studi Dokumentasi adalah pengumpulan data berupa dokumen-dokumen penting (Bungin, 2017).

Dari hasil wawancara dan observasi kemudian peneliti menganalissi menggunakan metode kualitatif. Metode analisis data yang digunakan adalah metode yang dikemukakan oleh Miles \& Huberman yaitu proses analisis data yang dibagi dalam tiga bagian yaitu reduksi data, display data dan verifikasi data. (Miles B, 1992) (Djani, 2005)

\section{HASIL DAN PEMBAHASAN}

\section{Analisis Data Hasil Interview dengan Dosen Bahasa Inggris Prodi PAI}

Temuan ini merupakan hasil wawancara dengan 3 orang dosen bahasa Inggris pada pendidikan agama islam fakultas tarbiyah dan ilmu keguruan IAIN Langsa mereka adalah Mh, NA, dan Wh. Mereka merupakan dosen-dosen yang sudah berpengalaman 4 sampai 8 tahun. Untuk mendapatkan data yang akurat peneliti mengajukan 15 butir pertanyaan yang dilakukan di ruang kerja beliau masing-masing kita telah memahami bahwa dalam rangka menghadapi era globalisasi dan informasi yang begitu terbuka dan cepat maka mahasiswa pada semua program studi dalam hal ini khususnya program studi pendidikan agama islam perlu meningkatkan kompetensi berbahasa asing khususnya bahasa Inggris, agar mereka dapat bersaing atau berkompetisi dalam era glibalisasi ini baik di bidang pengetahuan, informasi maupun dalam meperoleh kesempatan pekerjaan.

Oleh karena itu semua mahasiswa dari berbagai program studi perlu terus menerus dicari solusinya dalam meningkatkan kompetensi berbahasa Inggris melalui proses pembelajaran yang efektif dan efisien. Berkaitan dengan hal tersebut, Bapak Mh menjelaskan bahwa semua mahasiswa harus ditingkatkan kemampuan atau kompetensi berbahasa Inggrisnya dengan baik dan lancar agar mereka mudah mengakses dan berkomunikasi dengan masyarakat internasional sehingga dapat berkompetisi baik dalam peningkatan pendidikan maupun dalam hal yang lain. Hal ini senada dengan penjelasan Ibu NA yang menyataka bahwa mahasiswa Prodi PAI dan juga yang lain sangat penting ditingkatkan kompetensi 
bahasa inggrinya karena merekaakan melanjutkan pendidikan ke jenjang yang lebih tinggi (S2/S3) baik di dalam atau pun di luar negeri. Bahkan kini, sudah menjadi suatu syarat yaitu harus lulus TOEFL. Demikian pula penjelasan dari Ibu Wh yang juga merupakan salah satu dosen bahasa Inggris di Prodi PAI menyatakan bahwa untuk melanjutkan pendidikan, mencari kerja, menjalankan bisnis, dan lain-lain harus mempunyai kompetensi yang baik dalam hal ini mampu menguasai Bahasa Inggris yang baik karena banyak informasi dan lain sebagainya selalu disampaikan dalam istilah Bahasa Inggris maka mereka perlu menekuninya dengan baik. Dari pendapat-pendapat di atas, dapatlah disimpulkan bahwa semua mahasiswa Fakultas Tarbiyah, khususnya mahasiswa PAI harus meningkatkan kompetensi berbahasa Inggrisnya karena bahasa Inggris adalah bahasa ilmu pengetahuan dan pergaulan internasional.

Untuk meningkatkan kompetensi berbahasa Inggris yang baik dan benar mahasiswa perlu mempelajari dan memahami 5 kompetensi/skill yaitu reading skill, speaking, writing, listening, dan penguasaan vocabulary skill. Penegasan di atas didukung oleh penjelasan yang disampaikan oleh Ibu Wh yang menyatakan bahwa: untuk mampu menguasai bahasa Inggris yang baik dan lancar, learner atau dalam hal ini mahasiswa perlu meningkatkan di bidang skill tersebut di atas (reading skill, speaking, writing, listening, dan penguasaan vocabulary skill).

Demikian juga dengan penjelasan dari Ibu NA yang menyatakan bahwa mahasiswa mutlak penting untuk menguasai 5 skill bahasa Inggris seperti yang tertera di atas disertai dengan praktiknya sehari-hari. Demikian pula pernyataan tersebut didukung oleh Bapak Mh yang menjelaskan senada dengan yang dijelaskan di atas dengan menyebutkan bahwa apa yang dipelajari dari dosen sebenarnya mahasiswa harus mempraktikkannya baik secara individu maupun secara kelompok baik dalam materi reading, speaking, writing, listening, dan vocabulary sehingga lama-lama akan menjadi terbiasa sehingga dapat melakukannya dengan lancar.

Dari beberapa paparan yang disampaikan oleh para dosen tersebut dapat disimpulkan bahwa cara untuk memperlancar penguasaan bahasa Inggris dengan baik mahasiswa diharuskan untuk fokus dan sungguh-sungguh untuk mendalami dan memahami terlebih dahulu pengusaaan keempat kompetensi tersebut di atas (reading, speaking, writing, listening) secara kontinu.

Peningkatan kompetensi berbahasa Inggris pada mahasiswa melalui kompetensi-kompetensi tersebut di atas juga harus didukung oleh penerapan atau mengaplikasikan variasi metode atau strategi dan juga pendekatan yang dapat memotivasi atau mengaktifkan mahasiwa dalam mengikuti proses belajar mengajar. Lebih lanjut ibu NA mengatakan bahwa dalam mengajar reading mahasiswa disuruh untuk membuat pertanyaan-pertanyaan (making question), menyimpulkan isi teks, dan memprediksikannya (reciprocal teaching). Sehingga mereka dapat memahami teks secara komprehensif. Dalam mengajar speaking, ibu 
Nina menggunakan metode debat (debating). Sedangkan dalam mengajar writing, ia menggunakan strategi mind mapping. Bila ia mengajar untuk peningkatan penguasaan vocabulary dan listening mahasiswa disuruh untuk banyak membaca teks bahasa Inggris yang pendek serta untuk sering mengikuti program TV dalam bahasa Inggris.

Begitu juga penjelasan Ibu Wh yang senada dengan Ibu NA menyatakan bahwa: "Untuk meningkatkan kompetensi berbahas Inggris, mahasiswa harus menguasai paling kurang 4 (empat) skill atau kompetesi yaitu reading, speaking, writing dan listening skill, serta dapat meningkatkan kemampuan penguasaan vocabulary. Dalam ia mengajar bahasa Inggris ia sering menggunakan atau mengaplikasikan metode yang bervariasi. Bila mengajar reading ia menggunakan metode Read dan Reteling. Bila mengajar Speaking menggunakan strategi atau metode Read and Speaking Practice. Dan dalam mengajar Writing ia menggunakan metode Read and developping paragraph. Dan untuk meningkatkan penguasaan listening dan vocabulary mahasiswa diharapkan sering membaca Novel (Reading Novel) dan Sing English Song". Berkaitan dengan hal di atas Bapak Mh mengungkapkan bahwa: "dalam mengajar Reading dan Speaking dia menggunakan strategi untuk menceritakan kembali isi teks secara komprihensive (Retell) dan menyuruh mahasiswa mencari kata-kata baru atau sukar dipahami. Dalam mengajar Speaking mahasiswa diajak untuk menceritakan tentang daily activities secara oraly untuk meningkatkan kemampuan mahasiswa dalam percakapan dan peningkatan penguasaan vocabulary yang lebih baik."

Dari uraian di atas, dapatlah dipahami bahwa dalam mengajar bahasa Inggris, dosen sangat diharapkan untuk menggunakan baik metode maupun strategi yang bervariasi sesuai dengan keadaan yang dihadapi di lapangan, agar tujuan pembelajaran yang diharapkan dapat tercapai.

Dari temuan di lapangan, dosen telah melakukan perannya dengan baik dalam proses pembelajaran bahasa Inggris dengan segala pengalamannya serta mencurahkan segala kemampuannya dalam melakukan bimbingan pembelajaran bahasa Inggris dengan menerapkan beberapa metode atau strategi yang dilakukan dalam proses pembelajaran dengan penuh tanggung jawab yang tinggi. Dalam upaya meningkatkan kecakapan mahasiswa dalam menguasai bahasa Inggris walaupun peningkatan kompetensi berbahasa Inggris mereka masih belum seperti yang diharapkan. Dalam hal ini, akan memaparkan beberapa konsep strategi pembelajaran bahasa Inggris agar dapat membantu mahasiswa untuk memudahkan dalam peningkatan kemampuan berbahasa Inggris serta dapat diimplementasikan oleh dosen pemangku mata kuliah tersebut dalam menjalankan proses pembelajaran. Strategi tersebut antara lain: 
a. Focus on Rule Playing.

Strategi ini memerankan 2 orang mahasiswa untuk mempraktekkan percakapan dan mempresentasikan di kelas, sehingga lambat laun akan menjadi familiar dalam berbahasa Inggris secara continue.

b. The Student are Obligeted to use English During The Class.

Dalam penerapan strategi ini, dosen diharapkan untuk mewajibkan mahasiswa berbahasa Inggris dalam berkomunikasi dilingkungan kelasnya, bila melanggar atau menggunakan bahasa lain dosen akan memberi sanksi pada mahasiswa tersebut sehingga mahasiswa merasa perlu untuk mentaatinya.

c. The Students are Given Assignment to make their own conversation and present it in the next meeting

Strategi ini mahasiswa diberi tugas membuat sendiri sebuah bentuk percakapan dan akan dipresentasikan pada pertemuan berikutnya dengan 2 orang yang saling berdiskusi (tanya jawab).

d. Using Visual Aid Such As English Dialogue presented by native Speakers

Dalam penerapan strategi ini, dosen menyediakan materi ajar dalam bentuk kaset atau CD dengan menggunakan Visual Aid yang diperankan oleh orang Inggris sendiri. Dengan demikian, mahasiswa bisa melatih listening dan meniru cara berbahasa Inggris yang benar dan meniru pronounciation, intonation dan style yang diperankan langsung oleh native speakers tadi.

e. Group Discussion on Up Dated Issues

Dalam mempraktekkan strategi ini, dosen membentuk kelompok diskusi dan mahasiswa mendiskusikan hal-hal atau masalah terkini. Dari paparan atau penjelasan di atas bisa disimpulkan bahwa dalam proses peningkatan kualitas berbahasa Inggris perlu digunakan strategi yang bervariasi agar mahasiswa termotivasi dan meningkatkan kreativitasnya dalam proses pembelajaran sehingga pemahaman dan penguasaan bahasa Inggris dapat ditingkatkan.

f. Monologue Presentation such as story telling or telling experiences.

Strategi ini, dosen mengajak mahasiswa untuk menceritakan pengalaman mereka sendiri dan mempresentasikan di depan kelas (story telling).

\section{Analisis data hasil interview dengan mahasiswa prodi PAI}

Dalam pelaksanaan interview ini peneliti mengajukan 15 pertanyaan dan semua pertanyaan ditulis dalam bahasa Indonesia. Hasil interview ini dilakukan dengan 10 orang responden yang merupakan mahasiswa program studi Pendidikan Agama Islam yaitu saudara ZA, Kh, EM, MH, ER, MS, MKA, FA, KWP dan AM. Untuk mencapai keberhasilan atau kesuksesan dalam suatu hal sesseorang harus mempunyai keyakinan atau keinginan yang tinggi untuk mencapai sesuatu yang diinginkan. Bila tidak demikian, maka hal yang diinginkan tidak akan berhasil. Begitu juga halnya dalam mengikuti pembelajaran bahasa Inggris untuk mencapainya atau menguasainya perlu keinginan dan motivasi yang kuat untuk 
meraihnya. Terkait dengan penjelasan di atas, hasil wawancara peneliti dengan 10 responden yang disebut di atas bahwa sebahagian besar mereka tidak begitu tertarik dan tidak mencintai bahasa Inggris. Sedangkan 3 orang dari mereka yaitu ER, ZA dan Kh senang belajar bahasa Inggris sehingga mereka sudah bisa sedikitsedikit memahami dan berbicara bahasa Inggris. Selanjutnya saudara KWP, EM, MH dan FA mengatakan bahwa mereka kurang berminat belajar bahasa Inggris karena payah dipahaminya, belum memahami bentuk-bentuk kalimat Tenses, cara baca yang sulit lain ditulis lain dibaca. Tapi bagi mereka yang bersemangat dan mencintai bahasa Inggris karena mereka menyadari bahwa menguasai bahasa Inggris sangat diperlukan zaman sekarang, karena mampu berbahasa Inggris akan memudahkan kita memahami istilah-istilah asing baik dalam teori-teori pendidikan maupun dalam berkomunikasi dengan orang asing. Sebagaimana penjelasan saudara ER, ZA dan Kh.

Dari hasil penjelasan mahasiswa di atas, dapatlah dipahami bahwa kurangnya kemampuan berbahasa Inggris dikalangan mahasiswa PAI dikarenakan rendahnya keinginan atau semangat dalam belajar bahasa Inggris, mereka masih kurang memahami tentang pentingnya atau manfaat menguasai ilmu tersebut, sehingga dalam proses pembelajaran mereka merasa kesulitan dalam memahami baik kemampuan membaca, menulis maupun skill lainnya.

Peningkatan kompetensi berbahasa Inggris The Learner, dalam hal ini mahasiswa prodi PAI disamping mempunyai keinginan dan bakat yang tinggi juga harus didukung dengan adanya beberapa bahan ajar seperti buku bacaan atau referensi agar mereka bisa belajar secara mandiri atau berkelompok di luar mengikuti proses pembelajaran di lokal dengan dosen. Dari uraian di atas dapat disimpulkan bahwa kurangnya memiliki buku atau referensi dalam bahasa Inggris juga berpengaruh pada kurangnya aktivitas dalam mempelajari bahasa Inggris baik di dalam proses pembelajaran maupun belajar secara mandiri. Oleh karena itu, bagi mahasiswa perlu melengkapi referensi yang mencukupi agar mereka mudah untuk belajar secara continue.

Selanjutnya dalam mengikuti proses pembelajaran bahasa Inggris, mereka menghadapi kendala-kendala, terutama dalam memahami teks karena mereka kurang menguasai pembendaharaan kosa kata (vocabulary), serta sukar membacanya. Hal ini sesuai dengan penjelasan saudara KWP, Kh dan MS yang mengatakan bahwa mereka payah memahami teks dan membacanya karena banyak sekali kata-kata yang sukar mengartikannya serta payah untuk memahami bentuk kalimat (Tenses) yang berbeda-beda, karena berbeda bacaan dengan tulisannya.

Usaha peningkatan kompetensi berbahasa Inggris mahasiswa terlebih dahulu mampu menguasai beberapa skill atau kompetensi dalam pembelajaran bahasa Inggris diantaranya ialah Reading, Speaking, Writing dan Listening serta penting juga penguasaan vocabulary secara terus-menerus. Dalam hal ini saudara 
AM dan EM beserta kawan-kawannya menjelaskan bahwa dosen bahasa Inggris mengajar kami Reading, Speaking dan Writing dengan menyuruh kami membaca teks dan menulis cerita-cerita pendek serta berbicara dalam bahasa Inggris bila ada kesalahan dosen memkoreksinya dengan cara mengulang kembali.

Dari penjelasan di atas dapat disimpulkan bahwa untuk menguasai bahasa Inggris mahasiswa harus mempunyai kepercayaan diri (self convidence), keinginan yang kuat atau bersungguh-sungguh serta rajin membaca dan suka mempraktek apa yang telah dipelajari sehingga semakin hari akan semakin lancar.

\section{Hambatan dan solusinya dalam peningkatan kompetensi berbahasa Inggris Prodi PAI}

Dalam melaksanakan proses pembelajaran bahasa terutama sekali dalam melaksanakan Teaching and Learning English tentu ada hambatan-hambatan yang kita hadapi begitu juga hal nya bagi mahasiswa yang mempelajari bahasa kedua dan masih asing bagi mereka. Sejalan dengan itu, Ibu NA mengatakan bahwa: "Banyak hambatan-hambatan dalam mengajar bahasa Inggris antara lain kurangnya minat atau motivasi mahasiswa dalam mengikuti pembelajaran bahasa Inggris, mungkin mereka menganggap tidak begitu penting bagi mereka karena bukan mata kuliah jurusannya, disamping itu juga mungkin dipengaruhi background pada pendidikan sebelumnya dijenjang SLTP maupun di SLTA.

Begitu juga pernyataan Pak Mh yang mengatakan tantangan kita dalam mengajar bahasa Inggris pada mahasiswa yang bukan jurusannya adalah minatnya yang masih rendah dan motivasi untuk membaca juga masih belum menjiwai mungkin mereka merasa tidak begitu penting tentang pelajaran bahasa Inggris. Begitu juga penjelasan Ibu Wh yang menyatakan bahwa: "Setelah belajar di kelas mereka kurang termotivasi untuk mempraktekkan apa yang telah dipelajarinya, keinginan membaca juga masih rendah, sehingga dalam mengikuti pembelajaran banyak menghadapi kendala-kendala. Adapun hambatan-hambatan yang dihadapi yaitu

a. Berdasarkan temuan di lapangan bahwa rendahnya kompetensi berbahasa Inggris mahasiswa disebabkan banyak dari mereka mengatakan kurang bahkan tidak mencintai untuk belajar bahasa Inggris. Akibatnya, dalam mengikuti proses pembelajaran bahasa Inggris, mereka tidak begitu serius dan fokus dalam pembelajarannya. Mereka menganggap memahami bahasa Inggris tidak begitu bermanfaat bagi mereka di masa depan.

b. Sarana pembelajaran seperti tersedianya audio visual masih sangat terbatas sehingga mengalami sedikit kendala dalam proses pembelajaran.

c. Waktu dan jumlah sks yang disediakan masih tidak memadai dalam proses pembelajaran yang diharapkan. 
Untuk mengatasi hambatan-hambatan tersebut, diperlukan solusi yang tepat dan akurat diantaranya sebagai berikut:

a. Mahasiswa PAI perlu merubah maind set nya atau pandangannya dalam mempelajari mata kuliah bahasa Inggris. Mereka belum menumbuhkan rasa cinta dan percaya diri serta penuh perhatian dalam mengikuti proses pembelajaran bahasa Inggris walaupun menghadapi kendala-kendala atau kesukaran dalam memahaminya atau menguasainya. Mungkin dimasa yang akan datang akan bermanfaat dalam kehidupan mereka.

b. Dosen memegang peranan penting dalam melaksanakan proses pembelajaran sehingga tujuan yang diharapkan dapat tercapai yaitu meningkatkan kemampuan berbahasa Inggris pada mahasiswanya. Dalam melakukan proses pembelajaran dosen diharapkan menerapkan metode atau strategi yang bervariasi dan menerapkan strategi baru yang ditemukan, sehingga dapat mendorong mahasiswa untuk lebih aktif dan kreatif dalam proses pembelajaran bahasa Inggris dengan baik dan lancar.

c. Pihak fakultas diharapkan dapat meningkatkan kuantitas sarana pembelajaran seperti visual aid dan lain-lain sehingga proses pembelajaran tidak terkendala atau terhambat.

\section{KESIMPULAN}

Adapun kesimpulan dari penelitian ini adalah:

1. Strategi peningkatan kompetensi berbahasa Inggris pada mahasiswa PAI fakultas Tarbiyah dan Ilmu Keguruan IAIN Langsa, dengan menerapkan berbagai strategi pembelajaran terhadap pengusaaan keempat kompetensi Bahasa Inggris yaitu reading, speaking, writing, listening secara kontinu

2. Adapun hambatan-hambatan dalam meningkatan kompetensi berbahasa Inggris pada mahasiswa PAI fakultas FTIK IAIN Langsa yaitu rendahnya kompetensi berbahasa Inggris mahasiswa dikarenakan mahasiswa tidak menyukai untuk belajar bahasa Inggris. Akibatnya, dalam mengikuti proses pembelajaran bahasa Inggris, mereka tidak begitu serius dan fokus dalam pembelajarannya. Mereka menganggap memahami bahasa Inggris tidak begitu bermanfaat bagi mereka di masa depan, serta Sarana pembelajaran seperti audio visual masih sangat terbatas sehingga mengalami sedikit kendala dalam proses pembelajaran, Waktu dan jumlah sks yang disediakan masih tidak memadai dalam proses pembelajaran yang diharapkan

3. Solusinya dalam meningkatkan kompetensi berbahsa Inggris pada mahasiswa PAI IAIN Langsa yaitu Mahasiswa PAI perlu merubah maind set nya atau pandangannya dalam mempelajari mata kuliah bahasa Inggris. Mereka harus menumbuhkan rasa cinta dan percaya diri serta penuh perhatian dalam mengikuti proses pembelajaran bahasa Inggris, serta dari dosen diharapkan dalam proses pembelajaran dapat menerapkan metode atau strategi yang 
bervariasi agar dapat menerapkan strategi baru yang ditemukan, sehingga dapat mendorong mahasiswa untuk lebih aktif dan kreatif dalam proses pembelajaran bahasa Inggris dengan baik dan lancar. Dari Pihak fakultas diharapkan dapat meningkatkan kuantitas sarana pembelajaran seperti audio visual dan lain-lain sehingga proses pembelajaran tidak terkendala atau terhambat.

\section{DAFTAR PUSTAKA}

Arikunto, S. (2012). Dasar-Dasar Evaluasi Pendidikan (Ke 1). Bumi Aksara, Jakarta.

Bungin, B. (2017). Metodologi Penelitian Kualitatif. PT Raja Grafindo Persada.

Daryanto. (2009). Panduan Proses Pembelajaran Kreatif dan Inovatif. AV Publisher.

Djani, F. M. dan. (2005). Metode Penelitian Sosial. PTIK dan Restu Agung.

Majid, A. (2018). Strategi Pembelajaran. PT Rosda Karya.

Malan Abdullah. (2012). Jejak sejarah Abdus-Samad al-Palimbani. IAIN Raden Fatah.

Miles B, M. dan M. H. (1992). Analisis Data Kualitatif, Buku Sumber tentang Metode-Metode Baru. In UIP. UIP.

Sambayu, M. P. \&. (2015). Meningkatkan Kemampuan Berbahasa Inggris Mahasiswa Program Studi Pendidikan Bahasa Inggris FKIP-UNA dengan Literature Approach.

Schutz, R. (2017). Stephen Krashen's Theory of Second Language Acquestion.

Sudjana, N. (2013). Dasar-Dasar Proses Belajar Mengajar. Sinar Baru Algesindo, Bandung.

Sugiyono. (2017). Metode Penelitian Kuantitatif, Kualitatif dan R \& D. Alfabeta. 
